\title{
Pengembangan Sistem Pendampingan Usaha Berkelanjutan Bagi UMKM Berbasis Sistem Manajemen Kinerja
}

\author{
Mohammad Riza Radyanto ${ }^{1}$, Endro Prihastono ${ }^{1}$ \\ ${ }^{1}$ Program Studi Teknik Industri \\ Fakultas Teknik, Universitas Stikubank (Unisbank) Semarang \\ Jl Kendeng V Bendan Ngisor Gajahmungkur Semarang Jawa Tengah Kode pos 50233 \\ email : rizaradyanto@edu.unisbank.ac.id \\ doi: https://doi.org/10.31315/opsi.v13i1.3467
}

Received: $11^{\text {th }}$ June 2020; Revised: $21^{\text {st }}$ June 2020; Accepted: $25^{\text {th }}$ June 2020;

Available online: $30^{\text {th }}$ June 2020; Published regularly: June 2020

\begin{abstract}
During 2015-2018, Micro and Small and Medium Enterprises (MSMEs) entrepreneurs are faced with complex and multidimensional business problems influenced by internal and external factors. they are faced with problems that are classified into 5 main problems: marketing, finance, product legality, human resources, and packaging. The limited number of workers also affects business performance, where the average number of operators is 1-3 people per MSME, so steps are needed to maintain business performance namely through business assistance by outsiders. The purpose of this research is to produce a new system in the form of a continuous business assistance model involving 5 elements Penta helix: government, academia, business, community, and business assistants. The method used is a case study, a literature study based on gap analysis of previous research. The results obtained from this study are a new system in the form of a sustainable assistance model with 23 key performance indicators from 5 aspects of business based on a Performance Management System. In the future with this system, it is expected that Indonesian MSMEs have business resilience and sustainability.
\end{abstract}

Keywords: Business Resilience; Penta Helix System; Sustainable Business Assistance; Performance Management System

\begin{abstract}
ABSTRAK
Selama 2015-2018 pelaku Usaha Mikro Kecil dan Menengah (UMKM) dihadapkan pada permasalahan usaha yang kompleks dan multidimensi dipengaruhi oleh faktor internal dan eksternal .Daya tahan usaha bagi UMKM dari tahun ke tahun sudah terbukti tangguh terutama saat krisis ekonomi.Tapi dalam menjalankan usahanya mereka dihadapkan pada permasalahan yang diklasifikasikan menjadi 5 masalah utama yaitu:pemasaran, keuangan, legalitas produk, SDM dan Kemasan.Keterbatasan jumlah pekerja juga mempengaruhi kinerja usahanya dimana rerata jumlah pelaksana usaha sebanyak 1-3 orang per UMKM, sehingga dibutuhkan langkah untuk mempertahankan kinerja usahanya yaitu melalui pendampingan usaha oleh pihak luar.Tujuan dari penelitan ini adalah menghasilkan sebuah sistem baru dalam bentuk model pendampingan usaha berkelanjuta melibatkan 5 unsur pentaheliks yaitu: pemerintah, akademisi, bisnis, komunitas dan pendamping.Metode yang dipakai adalah studi kasus, studi literatur berdasarkan gap analisis dari penelitian terdahulu.Hasil yang diperoleh dari penelitian ini adalah sebuah sistem baru dalam bentuk model pendampingan berkelanjutan dengan 23 indikator kinerja utama dari 5 aspek usaha berdasarkan Sistem Manajemen Kinerja.Di masa mendatang dengan adanya sistem ini diharapkan UMKM Indonesia memiliki ketahanan dan keberlanjutan usaha.
\end{abstract}

Kata Kunci: Daya Tahan Usaha; Unsur Pentaheliks; Pendampingan Usaha Berkelanjutan; Sistem Manajemen Kinerja

\section{PENDAHULUAN}

Kementerian Koperasi dan UMKM RI tahun 2013 mengacu pada data Biro Pusat Statistik (BPS) menunjukkan bahwa jumlah UMKM secara nasional ada 57.895.791 dengan memberikan sumbangan terhadap Pendapatan
Domestik Bruto (PDB) mencapai Rp 5.440 triliun atau 60,3\% dari total PDB.Dengan menyerap tenaga kerja sebesar 114.144.082 jiwa sehingga UMKM mempunyai peran penting dan strategis dalam pembangunan ekonomi nasional.Dalam cakupan yang lebih kecil, data dari Dinas Koperasi dan UKM Jawa 
Tengah telah membina 120.781 UMKM yang menyerap 822.648 tenaga kerja di seluruh provinsi ini pada Agustus 2017. Pertumbuhan usaha di sektor ini membuka peluang bagi UMKM untuk mengembangkan kegiatan produksinya agar dapat bertahan di tengah persaingan usaha yang sangat ketat. Kinerja usaha mikro dapat dinilai dari kemampuan perusahaan untuk menciptakan proses yang efektif dan efisien dalam menghasilkan produk baik barang maupun jasa. Di sisi yang lain masih banyak UMKM memiliki permasalahan yang menghambat kelangsungan usahanya.

UMKM memiliki keterbatasan sumber daya untuk menerapkan sistem manajemen kinerja jika dibandingkan dengan perusahaan besar karena adanya tingkat perbedaan daya saing, struktur organisasi dan jenis manajemen praktek yang diterapkan. Selain itu menurut instansi ini hampir sebagian besar binaannya berskala usaha mikro dengan omset maksimum sebesar Rp.300.000.000 per tahun dan aset maksimum sebesar Rp.50.000.000 tidak termasuk rumah dan tanah. Dengan keterbatasan tersebut mengakibatkan UMKM pada setiap tahapan proses pembuatan produknya menggunakan tenaga konvensional dan peralatan sederhana. Dengan penggunaan teknologi yang sederhana ini, dimungkinkan terjadinya inefisiensi yang menimbulkan pemborosan baik dalam penggunaan bahan baku, proses produk, cacat produk bahkan dalam penggunaan energi. Permasalahan rendahnya tingkat efisiensi dan efektivitas dalam produksi menjadi perhatian utama yang harus dipecahkan permasalahannya

Salah satu cara untuk menyelesaikan permasalahan tersebut adalah dengan menerapkan Sistem Manajemen Kinerja pada UMKM.

\subsection{UMKM dan Permasalahannya}

Berdasarkan dari hasil penelitian yang dilakukan selama 4 tahun sejak 2015 dalam kapasitasnya sebagai Konsultan Pendampingan
UMKM pada Dinas Koperasi dan UKM Provinsi Jawa Tengah, telah dilakukan pemetaan permasalahan utama sebanyak 5 permasalahan terbesar yang dihadapi UMKM, diantaranya: (1)Pemasaran (2)Permodalan (3)Kemasan Produk (4)Legalitas Produk dan (5) Sumber Daya Manusia (SDM) seperti tercantum dalam Tabel 1.

Dari pemetaan tersebut diberikan penjelasan bahwa pada 2015 dari total 317 permasalahan UMKM: pemasaran merupakan permasalahan yang sering dijumpai oleh UMKM yaitu sebesar 34\% dimana sebagian besar hanya dapat melakukan pemasaran produknya dalam lingkup regional (satu kota atau kabupaten atau satu provinsi). Kedua adalah terbatasnya permodalan sebesar 30\% dimana menyebabkan berkurangnya kemampuan dalam melakukan produksi dan keterbatasan alat. Permasalahan kurang menariknya Kemasan Produk (11\%) menjadi permasalahan ketiga sedangkan Legalitas Produk (Izin Pangan Industri Rumah Tangga/PIRT) dan Izin Usaha (Nomer Induk Berusaha atau NIB) sebesar $15 \%$ dan terakhir adalah permasalahan Sumber Daya Manusia (7\%). Tren yang sama diperoleh dari tahun ke tahun hingga 2018, dengan 5 permasalahan terbesar utama yang dihadapi UMKM merupakan permasalahan yang sama.

Pada 2016 dilakukan penelitian di 33 Kabupaten dan Kota Jawa Tengah, diperoleh data bahwa dari 1.427 UMKM sekitar 64,7\% atau sebanyak 923 UMKM memiliki karyawan sebanyak 1 sampai 3 orang. Sebanyak 409 UMKM $(28,7 \%)$ memiliki karyawan sebanyak 4-10 orang, 85 UMKM (6,9\%) memiliki karyawan sebanyak 11-30 orang dan sisanya 0,7 $\%$ memiliki karyawan sebanyak $>30$ orang.

Dari Tabel 2 dinyatakan bahwa UMKM yang memiliki 1-3 karyawan pada umumnya memperkerjakan keluarga terdekat mulai dari suami, istri, anak atau kerabat. Hal tersebut menunjukkan bahwa lemahnya kuantitas SDM pengelola akan mempengaruhi profesionalisme

Tabel 1. Persentase Permasalahan UMKM di Jawa Tengah 2015-2018

\begin{tabular}{|c|c|c|c|c|c|c|c|}
\hline \multirow{2}{*}{ Tahun } & \multirow{2}{*}{ Jumlah } & \multirow{2}{*}{ Pemasaran } & \multirow{2}{*}{ Permodalan } & \multirow{2}{*}{ Kemasan } & \multirow{2}{*}{ Legalitas } & \multirow{2}{*}{ SDM } & \multirow{2}{*}{ Lain-lain } \\
\hline & & & & & & & \\
\hline 2015 & 317 & 34 & 30 & 11 & 15 & 7 & 3 \\
\hline 2016 & 436 & 34 & 17 & 9 & 9 & 10 & 21 \\
\hline 2017 & 749 & 28,5 & 15,6 & 10.8 & 10,7 & 7,3 & 27,1 \\
\hline 2018 & 646 & 34,9 & 15,8 & 11,8 & 5,3 & 10,6 & 21,6 \\
\hline
\end{tabular}


Tabel 2 . Klasifikasi UMKM Menurut Jumlah Karyawan

\begin{tabular}{lll} 
Jumlah & \multicolumn{1}{c}{ Jumlah } & \multirow{2}{*}{ Persentase } \\
\cline { 2 - 3 } Karyawan & \multicolumn{1}{c}{ UMKM } & \\
\hline 1-3 orang & 923 & $64,7 \%$ \\
4-10 orang & 409 & $28,7 \%$ \\
11-30 orang & 85 & $6,0 \%$ \\
>30 orang & 10 & $0,7 \%$ \\
Total & $\mathbf{1 4 2 7}$ & $\mathbf{1 0 0 \%}$ \\
\hline
\end{tabular}

pengelolaan usahanya dan mempengaruhi kinerja.

\subsection{Daya Tahan Usaha}

Winnard, et.al (2013) menyatakan bahwa pelaku usaha akan selalu menyusun strategi yang tangguh sehingga dapat bertahan dalam sebuah kondisi yang tidak pasti atau dalam sebuah lingkungan yang kompetitif. Salah satu sumber ketidakpastian adalah ketidakberlanjutan proses usaha yang diakibatkan dampak lingkungan, dampak ekonomi atau dampak sosial dan keterbatasan yang dihadapi sebuah usaha. Dalam jangka panjang pelaku usaha harus memiliki kemampuan untuk bertahanan dan berkelanjutan. Winnard berusaha untuk mengeksplorasi dua konsep yang saling berhubungan antara ketahanan dan keberlanjutan. Secara konseptual ketahanan merupakan kualitas dari sebuah sistem yang merupakan bagian ekologi dari sistem itu sendiri yang kompleks untuk kembali ke kondisi yang stabil setelah menerima berbagai gangguan (Bhamra et al., 2011). Ketangguhan dibutuhkan oleh sistem dan elemen-elemennya untuk mengatasi lingkungan eksternal yang bergolak mulai dari gangguan yang lebih kecil, untuk peristiwa berdampak besar (Bhamra et al., 2011; Wright et al., 2012).

Pendekatan untuk mengembangkan sistem ketahanan telah difokuskan pada pengurangan ketidakpastian, risiko, dan kerentanan. Ketidakpastian dapat dikurangi dengan meningkatkan pengetahuan seseorang dan oleh karena itu kemampuan untuk meramalkan karakteristik gangguan dan risiko perlu dihindari dengan menurunkan kemungkinan kejadian tertentu (Burnard dan Bhamra, 2011).

Kerentanan dapat ditingkatkan dengan mengurangi efek yang dimiliki gangguan pada sistem dengan menurunkan eksposur ke mereka, mengurangi sensitivitasnya terhadap mereka dan meningkatkan jangkauan respons yang tersedia sistem (Bhamra et al., 2011).
Somers (2009) menggambarkan ketahanan bisnis sebagai reaksi terhadap suatu peristiwa dan berpendapat bahwa ketahanan ditunjukkan setelah suatu peristiwa atau krisis terjadi. Hal tersebut akan menentukan apakah sebuah bisnis dapat bertahan dalam kondisi tertentu atau diperlukan sebuah peringatan dini.

Faktor ketahanan usaha untuk UMKM perlu diperhatikan dalam penelitian ini karena dengan menerapkan Sistem Manajemen Kinerja diharapkan ketangguhan usaha dapat terjadi dengan baik dan melalui perbaikan berkelanjutan atau continuos improvement kinerja usahanya semakin berkembang

\subsection{Pendampingan Usaha Penta Heliks \\ Di sisi lain pengakuan akan keberadaan} UMKM tidak bisa lepas dari peran pendampingan usaha untuk UMKM yang diatur oleh Peraturan Menteri Koperasi dan UKM Nomor: 02/Per/M.KUKM/1/2016 Tentang Pendampingan KUMK juga diterbitkannya Peraturan Menteri Koperasi dan UKM Nomor 24/Kep/M.KUKM/VIII/2016 Tentang Komite Standar Kompetensi Bidang Koperasi dan UMKM. Dari Permenkop yang terakhir di atas ditegaskan bahwa saat ini diperlukan pendamping UMKM yang berkompeten. Selain itu terbitnya Kepmen Ketenagakerjaan Nomor:181 tanggal 19 Juni 2017 Tentang Penetapan Standar Kompetensi Kerja Nasional Indonesia (SKKNI) bidang pendamping UMKM memberikan jaminan bagi UMKM untuk mendapatkan pendampingan secara profesional. Menurut Kementerian Koperasi dan UKM saat ini secara nasional jumlah tenaga pendamping KUMKM yang mampu direkrut sebanyak 4.242 orang terdiri dari PNS dan non PNS. Sementara melalui sinergi dengan BDS (Business Development Services) atau Lembaga Layanan Pengembangan Bisnis di seluruh Indonesia terdapat tambahan tenaga pendamping sebanyak 2.253 orang sehingga jumlah keseluruhan sebanyak 6.495 orang (Kemenkop dan UKM RI 2017).

Keberadaan Pusat Layanan Usaha Terpadu (PLUT), UMKM Center, Rumah Kreatif BUMN dan sarana lainnya menjadi salah satu faktor penunjang dalam mewujudkan pendampingan UMKM yang berkesinambungan di Indonesia. Beberapa peraturan yang dikeluarkan oleh Pemerintah Daerah baik tingkat I maupun tingkat II menjadi landasan kebijakan dan regulasi yang mengatur tata cara, tatanan aturan dan batasan untuk melakukan 
pembinaan, pendampingan serta pemberdayaan UMKM.

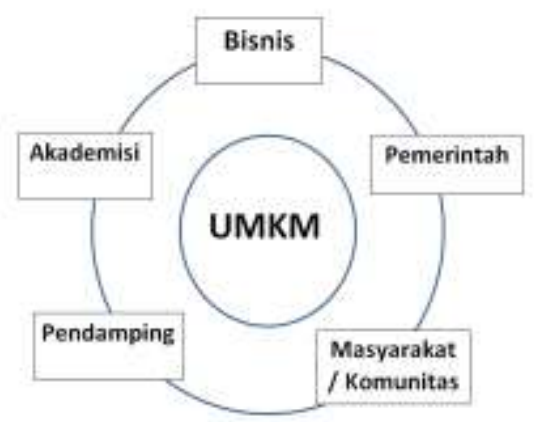

Gambar 1. Konsep Pendampingan Usaha Penta Heliks

Dari penjelasan yang telah dijabarkan diperoleh kesimpulan bahwa dalam mewujudkan pendampingan usaha yang berkelanjutan diperlukan sinergitas unsur penta heliks yaitu : pemerintah, swasta , akademisi , komunitas masyarakat dan pendamping itu sendiri selain peran kebijakan pemerintah melalui diterbitkannya peraturan dan regulasi yang mendukungnya.

\subsection{Sistem Manajemen Kinerja}

Neely (1995) menyatakan kinerja yang dicapai dari sebuah usaha merupakan fungsi dari efisiensi dan efektivitas usaha tersebut, sehingga pengukuran kinerja dapat didefinisikan sebagai proses kuantifikasi efisiensi dan efektivitas tindakan dalam bentuk metrik. Sementara Moullin (2003) menyimpulkan bahwa kinerja organisasi diukur dengan menentukan "Seberapa baik organisasi itu dikelola" dan "Berapa nilai yang diberikan organisasi untuk pelanggan dan pemangku kepentingan lainnya". Pengukuran kinerja merupakan sistem terstruktur yang disusun mulai dari: (1) proses pengumpulan data kinerja, (2) pemantauan kinerja , dan (3) penilaian informasi tentang suatu kegiatan organisasi, untuk mencapai tujuan dan sasaran yang diusulkan.

Secara umum Neely (1998) menyatakan bahwa fungsi pengukuran kinerja dapat dikategorikan menjadi 4 aspek yaitu: (1)Mengecek dan mengetahui posisi perusahaan, sejauh mana status terkini dan memonitor status sebelumnya kemudian membandingkannya, (2)Mengkomunikasikan posisi saat ini kepada pemangku kepentingan, pelangggan atau pekerja melalui laporan secara periodik, (3)Mengkonfirmasikan prioritas dimana data kinerja memberikan wawasan tentang apa yang penting bagi bisnis, dengan demikian mengekspos kekurangan yang memungkinkan organisasi untuk mengidentifikasi hal prioritas yang harus dilakukan, (4)Membantu organisasi fokus pada masalah tertentu dan mendorong orang untuk mencari cara untuk meningkatkan kinerja.

\subsection{Pengembangan Sistem Melalui Penentuan Key Indikator Performance \\ Key Performance Indicator (KPI) atau} Indikator Kinerja Utama sering disebut indikator kinerja terdiri dari serangkaian petunjuk tindakan yang berfokus pada aspek-aspek kinerja organisasi yang paling penting bagi keberhasilan organisasi saat ini dan di masa depan (Parmenter, 2007). Ini adalah aspek kuantitatif atau karakteristik kinerja. KPI sebagai kegiatan pengukuran dasar pengukuran kinerja, dan melalui KPI pengukuran kinerja dapat mentransfer tujuan strategis perusahaan ke tujuan yang terukur (Tsai \& Cheng, 2011).

Pengukuran kinerja produksi perlu didukung oleh KPI yang jelas dan layak. Menurut Slack et al. (2009) kebijakan yang didefinisikan dengan baik akan membuat indikator kinerja utama menjadi jelas dan dapat dicapai di tingkat operasional. Al-Najjar \& Kans (2006) juga berpendapat untuk pengembangan kebijakan pengukuran yang sesuai untuk KPI yang dikembangkan. Neely \& Bourne (2000) berpendapat bahwa tindakan yang didefinisikan dengan benar mengurangi ambiguitas untuk pencapaian mereka Setelah menetapkan tujuan kinerja, indikator kinerja yang sesuai harus diidentifikasi. UKM perlu memastikan bahwa metrik harus relevan, valid, dan layak. Indikator tersebut tidak hanya mencerminkan hasil kinerja, tetapi juga mengukur proses itu mencapai hasil dan kinerja masa depan.

\subsection{Perumusan Masalah}

Berdasarkan kajian literatur di atas diambil kesimpulan bahwa dengan adanya permasalahan UMKM di Jawa Tengah yang bersifat multidemensi baik dari sisi internal dan eksternal maka diperlukan sebuah sistem yang berfungsi untuk memecahkan persoalan tersebut. Dalam penelitian ini dikembangkan sistem berupa model Pendampingan Usaha Berkelanjutan berbasis Manajemen Pengukuran Kinerja UMKM untuk meningkatkan kinerja dengan memperhatikan proses pelaksanaan, menindaklanjutinya melalui tindakan yang 
menyelaraskan strategi usahanya dengan langkah nyata yang dilakukan berdasarkan KPI.

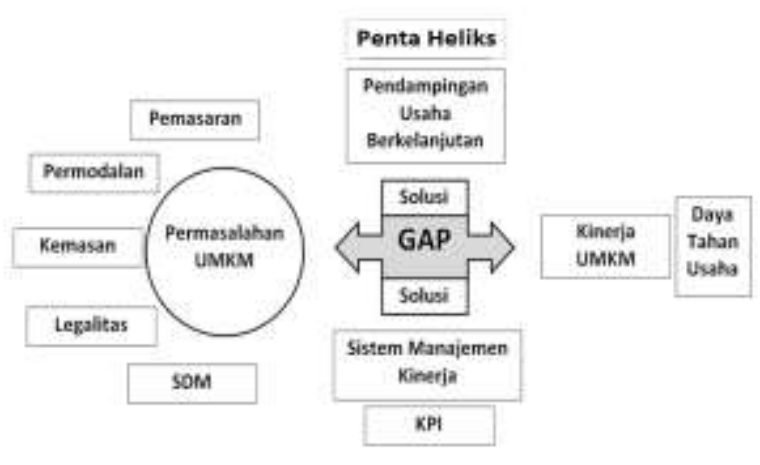

Gambar 2. Peta Permasalahan dan Solusi

Dari Gambar 2 dijelaskan peta permasalahan, gap yang ada beserta solusi yang diberikan untuk menyelesaikan 5 permasalahan tersebut berupa sebuah sistem yang akan dipakai oleh pemangku kepentingan dalam membina UMKM dan dapat digunakan oleh pelaku usaha dalam meningkatkan kinerja usahanya secara berkelanjutan.

\section{METODE}

Penelitian ini dilakukan di Klinik Konsultasi UMKM Center Dinas Koperasi dan UKM Jawa Tengah dengan kurun waktu pengambilan data selama 4 tahun mulai dari 2015-2018 dengan metode pengambilan data menggunakan kuesioner dan wawancara tatap muka dengan pelaku usaha kelas mikro, kecil dan menengah.

Urutan pelaksanaan penelitian meliputi: (1)Pemetaan permasalahan dengan responden UMKM yang ada di 35 Kabupaten/Kota Jawa Tengah, (2)Kajian Pustaka yang memuat penelitian terdahulu meneliti tentang daya tahan usaha, pendampingan usaha dan regulasi pemerintah, sistem manajemen kinerja yang membahas indikator kinerja serta pengembangan sistem yang selama ini belum ada penelitiannya khususnya di Jawa Tengah, (3)Pengembangan Sistem yang meliputi: Identifikasi Tujuan Kinerja, Identifikasi Area Pengukuran, Identifikasi Dimensi Pengukuran, dan Penentuan Key Performance Indicator / KPI

\subsection{Tahapan Identifikasi Tujuan Kinerja}

Tujuan dari tahapan pengembangan model ini adalah diperolehnya standar kinerja UMKM yang memiliki: (1)Jangkauan pemasaran luas baik di regional, nasional bahkan internasional, (2)Permodalan yang kuat baik melalui dana internal maupun melalui perbankan, (3)Kemasan produk yang memenuhi standar estetika dan layak untuk dipasarkan, (4)Legalitas produk berupa izin edar PIRT maupun BPOM atau Sertifikat Halal serta legalitas usaha dan (5)SDM yang berkapabilitas baik dan mampu menjalankan usaha secara profesional menjadi fokus utama.Selain itu aspek produksi dan aspek kualitas produk menjadi hal penting untuk diperhatikan.

\subsection{Tahapan Identifikasi Area Pengukuran}

UMKM memiliki lingkungan kompetitif yang unik dengan sumber daya terbatas dan pentingnya dilakukan diagnosa yang membantu mengidentifikasi penyebab masalah. Selain itu hasil dari identifikasi ini akan membantu pembuat keputusan mengetahui seberapa jumlah masalah itu berulang dan tindakan korektif apa yang akan dilakukan. Identifikasi ini akan melihat area gangguan atau akar penyebab masalah dari ke lima jenis permasalahan yang menyebabkan penurunan kinerja. Tahap merupakan langkah penting karena hasilnya akan digunakan untuk merancang pengukuran berdasarkan masalah riil dan solusi apa yang akan diambil.

\subsection{Tahapan Identifikasi Dimensi Pengukuran}

Dimensi pengukuran mencakup 7 aspek dimensi yaitu: (1) Hasil dan Capaian dari usaha yang akan diukur kinerjanya, (2) Input dari aspek yang akan diukur misalnya: SDM, bahan baku, atau sistem penunjang lainnya (3)Waktu, atau batasan sampai kapan pengukuran akan dilakukan secara periodik (4)Fokus pada 5 permasalahan utama, (5)Kualitas dari pengukuran, (6)Biaya yang diperlukan (7)Luaran yang dihasilkan

\subsection{Tahapan Penentuan KPI}

Pada tahapan ini beberapa indikator kinerja UMKM yang telah disepakati antara pelaku uasaha dan pendamping usahanya akan ditetapkan. Indikator harus memenuhi kriteria: (1)Spesifik dan jelas tujuannya, (2)Dapat dicapai sesuai kemampuan, (3)Terukur dengan pasti, (4)Realistik indikator harus nyata, dan (5)Targetable atau dapat dibuat sebagai target yang harus dicapai 


\section{HASIL DAN PEMBAHASAN}

\subsection{Hasil}

Model Pendampingan Usaha Berkelanjutan dikembangkan dengan memperhatikan beberapa faktor yang digunakan dalam Sistem Manajemen Kinerja. Terdapat 4 tahapan identifikasi yang harus dilakukan:

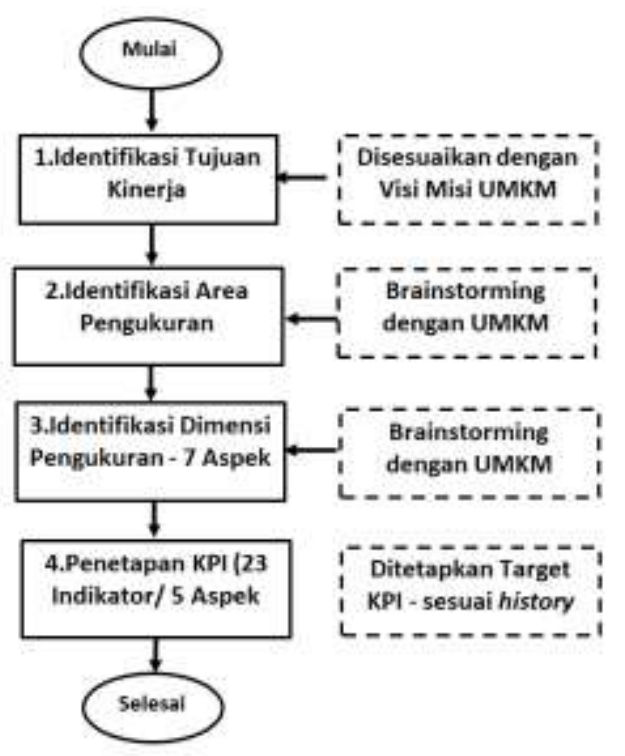

Gambar 3. Model Pengembangan Sistem Penentuan KPI UMKM

Dari KPI yang ditetapkan melalui 4 tahapan seperti dalam Gambar 3 diperoleh indikator kinerja utama yang mencakup 5 Aspek yaitu: (1) Aspek Keuangan, (2) Aspek Produksi, (3)Aspek Pemasaran, (4)Aspek SDM dan (5)Aspek Organisasi dan Kelembagaan.

Tabel 3. KPI Aspek Keuangan

\begin{tabular}{cll} 
No & \multicolumn{1}{c}{ Indikator } & \multicolumn{1}{c}{ Satuan } \\
\hline 1 & Omset Bersih & Rp/bulan \\
2 & Pembiayaan & Ada/tidak \\
3 & Laporan Keuangan & Ada/tidak \\
4 & Pajak & Rp/bulan \\
5 & Manajemen Keuangan & Nilai 1-3 \\
\hline
\end{tabular}

Tabel 3 menyatakan indikator yang digunakan untuk mengukur kinerja UMKM dari sisi Faktor Keuangan. Sementara Tabel 4 mencantumkan beberapa indikator kinerja yang termasuk aspek produksi yang terdiri dari 7 indikator

Sebagai permasalahan UMKM terbesar dari hasil pemetaan masalah, kinerja pemasaran UMKM yang dipantau mengacu pada 6 indikator tertera pada Tabel 5 :
Tabel 4 . KPI Aspek Produksi

\begin{tabular}{cll} 
No & \multicolumn{1}{c}{ Indikator } & \multicolumn{1}{c}{ Satuan } \\
\hline 1 & Kapasitas Produksi & Kg/bulan \\
2 & Peralatan & Nilai 1-3 \\
3 & Mutu Produk & Nilai 1-3 \\
4 & Inovasi & Ada/Tidak \\
5 & Volume Penjualan & Rp/bulan \\
6 & Mutu Produk & Nilai 1-3 \\
7 & SOP & Ada/Tidak \\
\hline
\end{tabular}

Tabel 5 . KPI Aspek Pemasaran

\begin{tabular}{cll} 
No & Indikator & Satuan \\
\hline 1 & Jumlah reseller - B2B & Orang \\
2 & Jumlah pelanggan-B2C & Orang \\
3 & Cakupan pemasaran & Nilai 1-3 \\
4 & Teknik Promosi & Nilai 1-3 \\
5 & Kemasan & Nilai 1-3 \\
6 & Merek & Ada/tidak \\
\hline
\end{tabular}

Tabel 6. KPI Aspek SDM

\begin{tabular}{|c|c|c|}
\hline No & Indikator & Satuan \\
\hline 1 & Jumlah karyawan & Orang \\
\hline 2 & Pelatihan yang diikuti & Nilai 1-3 \\
\hline
\end{tabular}

Tabel 7. KPI Aspek Organisasi dan Kelembagaan

\begin{tabular}{cll} 
No & Indikator & Satuan \\
\hline 1 & Aset Usaha & Rp \\
2 & Legalitas Usaha & Ada/tidak \\
3 & Legalitas Produk & Ada/tidak \\
\hline
\end{tabular}

Aspek Sumber Daya Manusia (SDM) sebagai bagian dari pengukuran kinerja pada pemetaan permasalahan UMKM, terdiri dari dari 2 indikator yang tertera pada Tabel 6 .

Aspek terakhir adalah Aspek Organisasi dan Kelembagaan mencakup 3 indikator:

Dari 5 aspek indikator yang telah ditetapkan kemudian tahapan selanjutnya adalah mengembangkan sebuah sistem pendampingan usaha yang berkelanjutan supaya menghasilkan UMKM yang memiliki daya tahan usaha tangguh dan mampu bersaing di tengah kondisi yang penuh dengan ketidakpastian.

Pada tahap awal dilakukan identifikasi terhadap 5 permasalahan utama yang ada pada UMKM dampingan. Pendampingan usaha dilakukan oleh pendamping yang diwakili dari unsur penta heliks yaitu: akademisi, bisnis, pemerintah, komunitas maupun pendamping. Pemerintah berperan sebagai regulator atau pihak yang membuat kebijakan dan memfasilitasi pelaksanaan proses pendampingan usaha, agar keberlangsungan pendampingan dapat terjaga. Unsur bisnis diwakili oleh perusahaan baik badan usaha milik 
negara atau daerah atau swasta, biasanya melalui Program Kemitraan Bina Lingkungan (PKBL). Akademisi sebagai representasi dari perguruan tinggi melaksanakan peran pendampingannya melalui unsur pengabdian masyarakat sebagai salah satu wujud dari Tri Dharma Perguruan Tinggi. Sistem pendampingan usaha yang telah dikembangkan, secara rinci digambarkan pada Gambar 4.

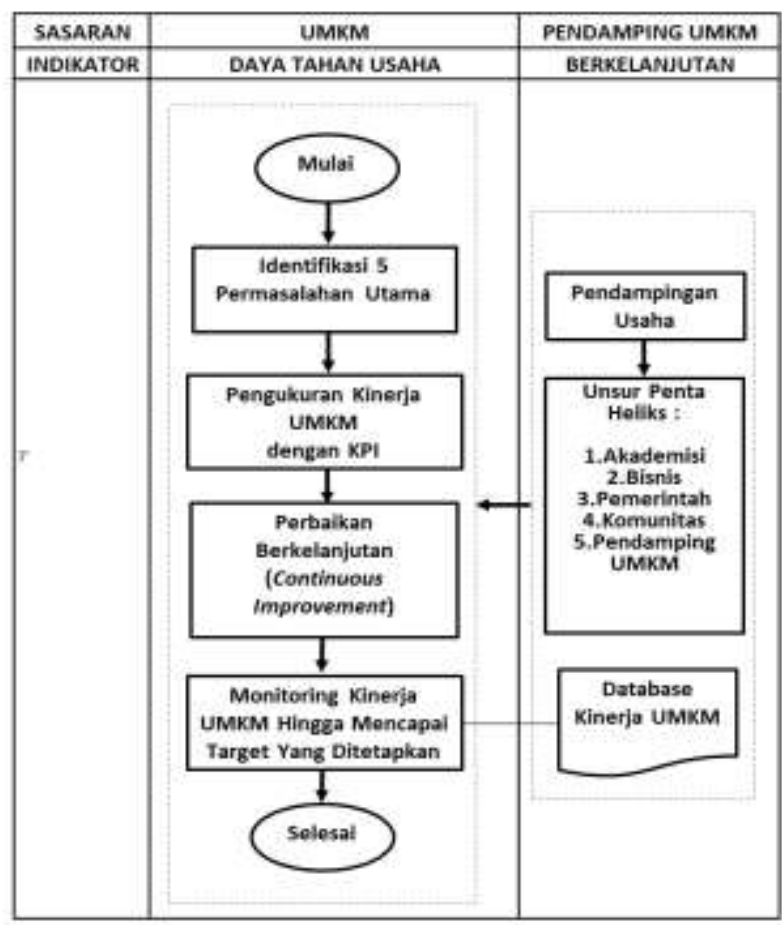

Gambar 4. Sistem Pendampingan Usaha Berkelanjutan

\subsection{Pembahasan}

Selama kurun waktu 2015-2018 model pendampingan yang dilakukan oleh pemangku kepentingan yang bertanggung jawab dalam pendampingan UMKM tidak tergambarkan dengan jelas. Pola pendampingan usaha memiliki karakteristik: bersifat temporer, tidak terukur dan tidak berkelanjutan dengan UMKM yang didampingi tidak tepat sasaran.

Sistem yang telah dikembangkan pada penelitian ini diharapkan dapat diaplikasikan ke seluruh Indonesia, karena potret UMKM yang dihasilkan dari pemetaan permasalahan di Jawa Tengah merupakan gambaran secara umum permasalahan usaha sektor ini di tingkat nasional.

Pada Gambar 4 juga dijelaskan bahwa setelah dilakukan perbaikan berkelanjutan berdasarkan hasil pengukuran kinerja, pendamping UMKM disarankan untuk memantau kinerjanya sehingga mencapai target yang diharapkan. Misalnya saat menilai kinerja berdasarkan indikator kinerja yang satuannya menggunakan nilai antara 1-3 digunakan jangkauan nilai: 1 (Nilai 60-70), 2 (Nilai 71-85) dan 3 (Nilai 86-100). Data hasil kinerjanya kemudian diarsipkan ke database pendampingan yang ada di masing masing pendamping dan digunakan sebagai bahan pengambilan keputusan untuk melakukan tindakan perbaikan secara berkelanjutan. Sehingga permasalahan dan solusi UMKM yang digambarkan pada Gambar 2 dapat diminimalisasi kesenjangannya.

\section{KESIMPULAN}

Dengan dihasilkannya sistem baru yang diterapkan dalam pendampingan usaha secara berkelanjutan, untuk masa mendatang diharapkan akan banyak UMKM yang memiliki kinerja prima, memiliki daya tahan usaha yang tangguh dan daya saing usaha yang tinggi.

Model pendampingan usaha tersebut diharapkan dapat meminimilasi permasalahan pemasaran, permodalan, kemasan produk, legalitas dan permasalahan SDM. Dengan mengacu pada 23 indikator kinerja yang terbagi dalam 5 aspek, kinerja UMKM dapat termonitor secara sistematis, sehingga jika dijumpai permasalahan dapat dilakukan perbaikan secara berkelanjutan atau continuous improvement.

Untuk menguji efektifitas model sistem ini ke depannya disarankan agar sistem baru ini dapat diterapkan secara kontinyu terhadap UMKM baik yang menghasilkan produk barang atau jasa di semua bidang kuliner, kerajinan atau produk lainnya.

\section{UCAPAN TERIMA KASIH}

Ucapan terima kasih diberikan kepada Dinas Koperasi dan UKM Provinsi Jawa Tengah atas kesempatan yang telah diberikan untuk bergabung menjadi Konsultan Pendamping UMKM Jawa Tengah pada UMKM Center Jawa Tengah selama 2015-2019 yang telah membantu terlaksananya penelitian ini.

\section{DAFTAR PUSTAKA}

Al-Najjar, B. Kans, M., (2006). A model to identify relevant data for problem tracing and maintenance cost-effective decisions: 
A case study. International Journal of productivity, 55(8), pp. 616-637

Bhamra, R., Dani, S. and Burnard, K. (2011), "Resilience: the concept, a literature review and future directions", International Journal of Production Research, Vol. 49 No. 18, pp. 5375-5393

Burnard, K. and Bhamra, R. (2011), "Organisational resilience: development of a conceptual framework for organisational responses", International Journal of Production Research, Vol. 49, pp. 5581-5599

Biro Pusat Statistik Republik Indonesia (2019), Data UMKM 1997-2013 , https:// www.bps.go.id/statictable /2014/01/30/ 1322/ tabel-perkembangan-umkm-padaperiode-1997--2013.html diakses 8 Juni 2019

Dinas Koperasi dan UKM Provinsi Jawa Tengah (2019), Data UMKM dan Koperasi https://dinkop-umkm.jatengprov.go.id/ content/index/2/73/6/data-koperasiumkm diakses 8 Juni 2019

Kementerian Koperasi dan UKM Republik Indonesia, (2016) Peraturan Menteri Koperasi dan UKM Nomor 24/Kep/M.KUKM/VIII/2016 Tentang Komite Standar Kompetensi Bidang Koperasi dan UMKM

Kementerian Koperasi dan UKM Republik Indonesia, (2017), Buku Kerja Konsultan Pendamping PLUT KUMKM, Pusat Layanan Usaha Terpadu

Kementerian Tenaga Kerja Republik Indonesia (2017), Kepmen Ketenagakerjaan Nomor:181 tanggal 19 Juni 2017 Tentang Penetapan Standar Kompetensi Kerja Nasional Indonesia (SKKNI) bidang pendamping UMKM

Kementerian Koperasi dan UKM Republik Indonesia, (2016) Peraturan Menteri Koperasi dan UKM Nomor: 02/Per/M.KUKM/1/2016 Tentang Pendampingan KUMK
Neely, A. Gregory, M. Platts, K., (1995). Performance Measurement System Design: A Literature Review and Research Agenda. International Journal of Operations \& Production Management, 15(4), pp. 80-116.

Neely, A. (1998). "Three models of measurement: theory and practice." International Journal of Business Performance Management 1(1): 47-64.

Neely, A. Bourne, M. Kennerley, M., (2000). Performance Measurement System Design: Developing and Testing a Process-based Approach. International Journal of Operations \& Production Management, 20(10), pp. 1119-1145

Parmenter, D., (2007). Key Performance Indicators: Developing Implementing and Using Winning KPIs. New Jersey: John Wiley \& Sons, Inc.

Slack, N. Chambers, S. Johnston, R. Betts, A., (2009). Operations and process management: principles and practice for strategic impact. 2nd ed. Harlow ; New York : Prentice Hall

Somers, S. ,2009, Measuring resilience potential: an adaptive strategy for organizational crisis planning. Journal of Contingencies and Crisis Management, 17(1), 12-23

Tsai, Y.C. Chen, Y.T., 2011. Analysing Key Performance Indicators (KPI) for Ecommerce and Internet Marketing of Elderly Product: A Review. Archives of Gerontology and Geriatrics, In Press, Corrected Proof.

Winnard, J, Adcord Andy, (2013) Surviving or Flourishing Integrating Business Resilience and Sustainability, Journal of Strategy and Management Vol. 7 No. 3, 2014 pp. 303-315 Emerald Group Publishing Limited 1755-425X

Wright, C., Kiparoglou, V., Williams, M. and Hilton, J. (2012), "A framework for resilience thinking", Procedia Computer Science, Vol. 8, pp. 45-52. 